\title{
Pengembangan Media Permainan Kartu Gambar Dengan Teknik Think Pair Share Pada Siswa Kelas 3 Sekolah Dasar Di Palopo
}

\author{
Yuni Faryanti Sukri ${ }^{1}$, Farida Indriani ${ }^{2}$ \\ ${ }^{1,2}$ Program Studi PGSD FKIP Universitas Cokroaminoto \\ 1yunifaryantisukri@yahoo.co.id \\ 2i.farida@yahoo.com
}

\begin{abstract}
ABSTRAK
Penelitian ini bertujuan untuk: 1) mengetahui kelayakan media permainan kartu gambar pada pembelajaran tematik-integratif dengan tehnik make a match, dan 2) mengetahui efektifitas media permainan kartu gambar pada pembelajaran tematik-integratif dengan tehnik think pair share untuk siswa kelas 3 MI DDI I Kota Palopo. Jenis penelitian ini adalah penelitian dan pengembangan atau Research and Developement (R \& D). Pengembangan dilakukan mengacu pada model pengembangan Dick \& Carey yang melalui 9 tahapan. Tahapan tersebut meliputi Identify Instructional Goals, Conduct Instructional Analysis, Analyze Learners and Context, Write Peformance Objectives, Develop Assessment Instruments, Develop Instructional Strategy, Develop and Select Instructional Materials, Design and Conduct Formative Evaluation of Instructional, Revise Instruction. Validasi produk melibatkan 1 dosen ahli media, 1 dosen ahli materi, 2 praktisi dan 2 teman sejawat. Subyek uji coba penelitian adalah siswa kelas 3 MI DDI I Kota Palopo tahun ajaran 2017/2018 yang terdiri dari 9 orang siswa pada uji coba kelompok kecil dan 29 orang siswa pada uji coba kelompok besar. Instrumen yang digunakan adalah pedoman wawancara, lembar penilaian kelayakan media pemainan kartu gambar, dan lembar observasi. Teknik pengumpulan data yang digunakan adalah teknik wawancara, penilaian produk, dan observasi. Teknik analisis data menggunakan analisis deskriptif, uji paired simple t test untuk keefektifan dan menggunakan konversi skor menjadi data kualitatif untuk kepraktisan. Hasil uji coba satu-satu dari penilaian ahli, paktisi dan teman sejawat menunjukkan media permainan kartu gambar dengan teknik make a match pada pembelajaran tematik-integratif layak digunakan dengan kriteria "Sangat Baik". Uji coba kelompok kecil hasilnya adalah mendapat respon yang positif dengan kriteria "Baik". Uji coba kelompok besar diuji keefektifan dan kepraktisan penggunaan produk. Keefektifan ditinjau dari hasil belajar peserta didik menunjukkan ada perbedaan rata-rata dari 81,23 menjadi 95,40. Ada peningkatan hasil belajar peserta didik yang ditunjukkan dengan nilai signifikansi sebesar 0,001 dengan taraf signifikansi 0,005. Kepraktisan penggunaan media ditinjau dari hasil observasi guru diperoleh prosentase $95 \%$ dan hasil observasi siswa diperoleh 88,75\% dengan masing-masing kriteria kepraktisan sama yaitu "Sangat Praktis".
\end{abstract}

Kata Kunci: Media Permainan Kartu Gambar, Teknik Think Pair Share

\section{PENDAHULUAN}

Proses pembelajaran merupakan suatu kegiatan melaksanakan kurikulum dalam suatu lembaga pendidikan, agar dapat mendorong siswa mencapai tujuan pendidikan yang telah ditetapkan oleh pemerintah. Pembelajaran di sekolah sebaiknya dirancang untuk mempermudah siswa dalam belajar. Oleh karena itu, guru tidak hanya dituntut untuk membuat lingkungan belajar yang nyaman, tetapi juga harus mampu menciptakan pembelajaran yang kreatif, aktif, efektif dan inovatif serta menarik perhatian siswa sehingga pseserta didik dapat memperoleh pengetahuannya sendiri.
Berdasarkan hasil observasi dengan salah satu guru di Sekolah Dasar di Palopo, diketahui bahwa kesiapan guru dalam melaksanakan proses kegiatan belajar mengajar belum maksimal terutama terkait perangkat pembelajaran. Walaupun guru-guru telah memperoleh pelatihan terkait perangkat pembelajaran, namun masih dirasa kurang dalam mempersiapkan segala sesuatu terkait kegiatan pembelajaran. Permasalahan lain yang dihadapi guru adalah media pembelajaran yang tidak semuanya tersedia di lingkungan sekolah, terutama untuk siswa kelas rendah yang harus mengetahui secara jelas dan nyata konsep maupun benda terkait tema-tema yang dibahas. Sebagai contoh, alat 
musik tradisional tidak semua siswa menjumpai alat musik tradisional dan mengenal alat musik tersebut.

Kendala lain yang dihadapi guru dalam melaksanakan pembelajaran adalah adanya perubahan strategi dalam kegiatan pembelajaran dimana guru harus bisa mengembangkan pembelajaran yang sesuai dengan kurikulum yang baru. Guru tidak hanya melakukan ceramah atau pembelajaran konvensional tetapi bagaimana guru mendorong motivasi siswa untuk aktif dan kreatif dalam mengikuti proses pembelajaran sehingga siswa dapat mengalami dan menemukan sendiri pengetahuannya. Selama ini banyak guru yang masih menggunakan metode ceramah secara klasikal tanpa menggabungkan metode lain maupun dengan penggunaan alat bantu dalam pembelajaran seperti media pembelajaran.

Pada dasarnya anak usia SD kelas 3 masih senang bermain. Namun, masih banyak guru yang menggunakan cara klasik tanpa menambahkan unsur permainan atau sejenisnya yang dapat menarik perhatian siswa, sehingga siswa lebih termotivasi dalam proses pembelajaran untuk mengikuti dan mempelajari suatu konsep materi yang diberikan. Guru seharusnya merancang pembelajaran yang memungkinkan adanya unsur permainan didalamnya. Dengan memasukkan unsur permainan siswa dapat teribat secara langsung dalam proses pembelajaran. Oleh karena itu, teknik yang dapat digunakan dalam penggunaan media permainan kartu gambar yaitu think pair share (berpikir berpasangan berbagi). Teknik ini menggunakan kartu, dimana setiap kartu akan diselipkan gambar maupun teks sebagai penjelasan dari suatu konsep materi yang dipaparkan dan setiap kartu memiliki pasangan yang sesuai dengan gambar maupun teks (Rusman, 2011: 223).

Berdasarkan permasalahan tersebut, maka dilakukan penelitian tentang pengembangan media permainan kartu gambar pada pembelajaran dengan teknik think pair share untuk siswa kelas III Sekolah Dasar di Palopo.

\section{METODE PENELITIAN}

Penelitian ini merupakan jenis penelitian pengembangan, yaitu suatu proses penelitian yang digunakan untuk mengembangkan suatu produk. Produk yang dihasilkan dari penelitian ini berupa media gambar dengan teknik think pair share pada pembelajaran untuk kelas 3 di Madrasah Ibtidaiyah DDI I Kota Palopo. Penelitian ini dilaksanakan di Madrasah Ibtidaiyah DDI I Kota Palopo dan subjek penelitiannya adalah siswa kelas 3 pada tahun pelajaran 2017/2018 sebanyak 29 orang.

Prosedur pengembangan media gambar terdiri dari 10 langkah, yakni identify instructional goals, conduct instructional analysis, analyze learners and contexts, write performance objectives, develop assessment instrument, develop instructional strategy, develop and select instructional materials, design and conduct formative evaluation of instruction, revise instruction, dan design and conduct summative evaluation.

Teknik pengumpulan data dalam penelitian ini menggunakan teknik observasi, wawancara dan dokumentasi. Sedangkan instrumen penelitian meliputi pedoman wawancara, lembar observasi dan foto kegiatan selama penelitian. Data-data yang diperoleh kemudian dianalisis sebagai berikut.

\section{Analisis data kualitas media}

Penilaian media pembelajaran berupa permainan kartu gambar dengan teknik think pair share meliputi penilaian media permainan kartu gambar dengan tema perkembangbiakan hewan dan tumbuhan. Penilaian kualitas media permainan kartu gambar meliputi aspek permainan kartu, aspek gambar dan aspek tampilan. Pada penilaian isi materi, aspek yang dinilai meliputi aspek kelayakan isi, aspek kebahasaan, dan aspek sajian. Data kuantitatif yang sudah didapatkan akan dihitung dan dikategorisasi sesuai dengan penilaian Widiyoko (2009: 238) dengan skala sangat baik, baik, cukup, kurang baik dan sangat kurang baik.

Selain secara kuantitatif, diambil juga data kualitatif deskriptif dalam bentuk komentar dan saran revisi. Data kuantitatif dan kualitatif ini kemudian dijadikan bahan untuk memperbaiki media permainan kartu gambar dengan teknik think pair share yang dikembangkan agar menghasilkan produk yang lebih baik dan sesuai dengan pembelajaran muapun kebutuhan siswa.

2. Analisis data wawancara

Data yang diambil dari wawancara siswa ini tentang tampilan, respon dan tanggapan siswa setelah menggunakan media permainnan kartu gambar dengan teknik think pair share. Hasil data wawancara yang diperoleh dianalisis sebagai berikut. 
a. Tabulasi data yang diperoleh, Hasil dari penilaian wawancara dihitung dari banyaknya jawaban "ya" untuk setiap pertanyaan dan memiliki skor 1 .

b. Mengkonversi rata-rata yang diperoleh menjadi nilai kualitatif sesuai dengan kriteria.

3. Analisis keefektifan

Data perbedaan hasil belajar peserta ddik sebelum menggunakan media dan setelah menggunakan media dianalaisis dengan uji statistik. Uji statistik yang digunakan adalah paired sample t test karena analisis melibatkan dua pelakuan pada subek yang sama terhadap suatu pengaruh. Kriteria penerimaan dan penolakan pada taraf signifikansi $5 \%$ dengan menggunakan signifikansi, yaitu jika signifikansi maka Hipotesis nol diterima dan sebaliknya jika tidak signifikan maka Hipotesis nol ditolak.

4. Analisis kepraktisan

Hasil data observasi yang dilakukan peneliti akan dianalisis sebagai berikut:

a. Tabulasi data yang diperoleh observer

Hasil dari penilaian observer dihitung dari banyaknya pilihan "Ya" untuk setiap pernyataan dan memiliki skor 1 .

b. Mengkonversi rata-rata yang diperoleh menjadi nilai kualitatif sesuai kriteria kepraktisan Soewandi (2005: 50) dalam tabel berikut.

Tabel 1. Kriteria kepraktisan

\begin{tabular}{cl}
\hline$\%$ Keterlibatan & Kepraktisan \\
\hline $0 \leq \mathrm{n} \leq 21$ & TidakPraktis \\
\hline $21 \leq \mathrm{n} \leq 41$ & Kurang praktis \\
\hline $41 \leq \mathrm{n} \leq 61$ & Cukup praktis \\
\hline $61 \leq \mathrm{n} \leq 81$ & Praktis \\
\hline $81 \leq \mathrm{n} \leq 100$ & Sangat praktis \\
\hline
\end{tabular}

c. Menganalisis kepraktisan produk media pembelajaran

Nilai rata-rata dari observasi kegiatan pembelajaran menggunakan media yang dikembangkan kemudian dicocokan dengan tabel. Kriteria kepraktisan observasi pembelajaran. Produk yang dikembangkan dikatakan memiliki kepraktisan yang baik, jika menimal tingkat kepraktisan yang dicapai adalah tingkat praktis.

\section{HASIL \& PEMBAHASAN}

A. Hasil Penelitian

Hasil penelitian terdiri atas (1) hasil uji coba produk, (2) hasil uji coba kelompok kecil, dan (3) hasil uji coba kelompok besar.

1. Hasil uji coba satu-satu

Pada tahap uji coba satu-satu, produk yang dihasilkan dilakukan validasi terhadap satu orang dosen ahli materi \& pembelajaran, satu orang dosen ahli media, dua orang guru kelas di lokasi penelitian, dua orang teman sejawat/guru dari luar lokasi penelitan.

a. Hasil penilaian ahli media

Hasil penilaian produk oleh ahli media berupa rerata skor dikonversikan menjadi nilai skala lima. Berdasarkan hasil penilaian produk media yang dikembangkan diperoleh nilai maksimum 95, nilai minimum 19, $\bar{X}_{i}=57$ dan $\mathrm{sb}_{\mathrm{i}}=12,67$.
Penilaian ahli media pada aspek permainan kartu yang terdiri dari 4 indikator penilaian diperoleh skor 18 , nilai maksimumnya 20 , nilai minimumnya 4 , $\bar{X}_{i}=12, \mathrm{sb}_{\mathrm{i}}=2,7$ dengan kriteria nilai "Sangat Baik". Pada aspek gambar terdiri dari 8 indikator penilaian diperoleh skor 34 , nilai maksimunnya 40 , nilai minimunnya 8 , $\bar{X}_{i}=24, \mathrm{sb}_{\mathrm{i}}=5,3$ dengan kriteria nilai "Sangat Baik". Aspek tampilan terdiri dari 7 indikator penilaian diperoleh skor 31, nilai maksimumnya 35 , nilai minimunnya 7 , $\bar{X}_{i}=21, \mathrm{sb}_{\mathrm{i}}=4,7$ dengan kriteria nilai "Sangat Baik".

b. Hasil penilaian ahli materi

Aspek penilaian yang diajukan pada ahli materi meliputi aspek kelayakan isi, aspek kebahasaan dan aspek sajian. Data hasil penilaian ahli materi dan pembelajaran secara keseluruhan diperoleh skor maksimalnya 115 , skor minimumnya $23, \bar{X}_{i}=69$, dan $\mathrm{sb}_{\mathrm{i}}=15,33$. Berdasarkan keseluruhan penilaian produk oleh ahli materi dan pembelajaran diperoleh skor $\mathrm{X}=94$, yang termasuk dalam kriteria nilai "Baik".

Penilaian ahli materi dan pembelajaran pada aspek kelayakan isi yang terdiri dari 9 indikator diperoleh skor 36, nilai maksimumnya 45 , nilai minimumnya 9 , 
$\bar{X}_{i}=27, \mathrm{sb}_{\mathrm{i}}=6$ dengan kriteria nilai "Baik". Pada aspek kebahasaan terdiri dari 7 indikator diperoleh skor 28, nilai maksimunnya 35 , nilai minimunnya 7 , $\bar{X}_{i}=21, \mathrm{sb}_{\mathrm{i}}=4,7$ dengan kriteria nilai "Baik". Pada aspek sajian terdiri dari 7 indikator penilaian diperoleh skor 28 , nilai maksimunnya 35 , nilai minimunnya 7 , $\bar{X}_{i}=21, \mathrm{sb}_{\mathrm{i}}=4,7$ dengan kriteria nilai "Baik".

c. Hasil Penilaian Praktisi

Berdasarkan penilaian dua orang guru, pada aspek kelayakan isi diperoleh skor 79 , nilai maksimum 90, nilai minimum $18, \bar{X}_{i}=54$, $\mathrm{sb}_{\mathrm{i}}=12$ dengan kriteria nilai "Sangat Baik". Pada aspek kebahasaan diperoleh skor 64, nilai maksimum 70 , nilai minimum $14, \bar{X}_{i}=42$, $\mathrm{sb}_{\mathrm{i}}=9,3$ dengan kriteria nilai "Sangat Baik". Sedangkan pada aspek sajian diperoleh skor 63, nilai maksimum 90, nilai minimum 18 , $\bar{X}_{i}=54, \mathrm{sb}_{\mathrm{i}}=12$ dengan kriteria nilai "Sangat Baik".

d. Hasil penilaian teman sejawat

Berdasarkan penilaian dua orang guru, pada aspek kelayakan isi diperoleh skor 77, nilai maksimum 90, nilai minimum $18, \bar{X}_{i}=54, \mathrm{sb}_{\mathrm{i}}=12$ dengan kriteria nilai "Sangat Baik". Pada aspek kebahasaan diperoleh skor 56 , nilai maksimum 70 , nilai minimum $14, \bar{X}_{i}=42, \mathrm{sb}_{\mathrm{i}}=9,3$ dengan kriteria nilai "Baik". Sedangkan pada aspek sajian diperoleh skor 61 , nilai maksimum 90 , nilai minimum $18, \bar{X}_{i}=54, \mathrm{sb}_{\mathrm{i}}=12$ dengan kriteria nilai "Sangat Baik".

e. Hasil semua penilaian materi

Berdasarkan hasil keseluruhan penilaian ahli materi diperoleh skor maksimum 575 , skor minimum $115, \bar{X}_{i}=345, s b_{i}=76,7$ dengan kriteria "Sangat Baik". Berdasarkan penilaian lima orang ahli materi dan pembelajaran, pada aspek kelayakan isi diperoleh skor 189 , nilai maksimum 225, nilai minimum $45, \bar{X}_{i}=135$, $s b_{i}=30$ dengan kriteria nilai "Baik". Pada aspek kebahasaan diperoleh skor 148, nilaimaksimum 175 , nilai minimum $35, \bar{X}_{i}=105, \mathrm{sb}_{\mathrm{i}}=23,3$ dengan kriteria nilai "Sangat Baik". Sedangkan pada aspek sajian diperoleh skor 152, nilai maksimum 175, nilai minimum $35, \quad \bar{X}_{i}=105$, $\mathrm{sb}_{\mathrm{i}}=23,3$ dengan kriteria nilai "Sangat Baik".

2. Hasil uji coba kelompok kecil

Uji coba kelompok kecil dilakukan pada 9 siswa kelas 3. Siswa tersebut dipilih secara representatif mewakili populasi. Dalam memilih siswa secara representatif perlu dipertimbangkan agar semua kelompok terwakili siswa yang berkemampuan tinggi, sedang dan rendah. Oleh karena itu, dalam pemilihan tersebut peneliti dibantu guru kelas 3. Tujuan utama dari pelaksanaan evaluasi dalam kelompok kecil, yaitu: (a) mengidentifikasi masalah-masalah yang mungkin dialami oleh siswa; dan (b) mengetahui tanggapan siswa dalam menggunakan media serta mengetahui perbaikan media dari aspek tampilan.

Berdasarkan hasil skor wawancara terhadap 9 siswa, diperoleh skor maksimumnya 63, skor minimumnya 0 , $\mathrm{Xi}=31,5$ dan $\mathrm{Sbi}=10,5$. Dari hasil wawancara, diperoleh skor keseluruhan 48 dengan kriteria nilai "baik". Hal ini berarti bahwa pada tahap uji coba penggunaan media permainan kartu gambar dengan teknik think pair share, siswa memiliki tanggapan yang baik dan positif.

\section{Hasil uji coba kelompok besar}

Secara keseluruhan observasi kegiatan guru pada proses pembelajaran dengan menggunakan media permainan kartu gambar diperoleh persentase skor $95 \%$ dengan kriteria kepraktisan "Sangat Baik". Sedangkan observasi kegiatan siswa diperoleh persentase skor sebesar $88,75 \%$ dengan kriteria kepraktisan "sangat baik".

Hasil analisis penskoran wawancara pada uji coba kelompok besar diperoleh skor maksimalnya 203, skor minimalnya 0 , $\bar{X}_{i}=101,5$ dan $\mathrm{sb}_{\mathrm{i}}=33,83$ dengan jumlah perolehan skor keseluruhan 186 berada pada kriteria "Sangat Baik".

Perbedaan keefektifan penggunaan media yang dikembangkan dilihat dari nilai hasil belajar siswa sebelum dan setelah menggunakan media dan analisis uji t. Karena perlakuan hanya diberikan pada subyek yang sama maka analisis uji $\mathrm{t}$ menggunakan paired sample t test. Dalam penelitian ini perhitungan paired simple $t$ test menggunakan program SPSS 17.0. Harga t berada pada $-4,816$ yang memiliki arti jika t hitung negarif, maka ratarata sebelum menggunakan media lebih rendah 
daripada setelah menggunakan media. Tabel di atas juga menunjukkan bahwa signifikansi (2tailed) berada pada tinggkat signifikan 0,001. Karena taraf signifikansi 0,05 bearti sigifikansi 2-tailed $=0,000<\alpha=0,05$ maka $H_{o}$ ditolak. Berdasarkan penjelasan tersebut, maka disimpulkan bahwa ada perbedaan yang signifikan terhadap hasil belajar siswa sebelum menggunakan media dengan setelah menggunakan media.

Pada aspek ketuntasan dengan perbandingan nilai kriteria ketuntasan minimal (KKM) di MI DDI Kota Palopo, maka siswa dikatakan tuntas secara individu jika memenuhi nilai KKM 75 dan secara klasikal siswa tuntas jika tingkat persentase mencapai $80 \%$. Dari hasil perolehan nilai siswa, diketahui bahwa sebelum menggunakan media yang dikembangkan diperoleh 6 siswa yang belum tuntas dan persentase ketuntasan kelas $79,31 \%$. Setelah menggunakan media diperoleh persentase ketuntasan secara klasikal $100 \%$.

\section{B. Pembahasan}

Secara statistik dapat dilihat bahwa terdapat perbedaan hasil belajar siswa sebelum dan setelah menggunakan media yang dikembangkan. Hal ini disebabkan karena konsep yang diberikan dalam media menggunakan gambar-gambar yang nyata yang sering dijumpai siswa serta menggunakan permainan kartu. Disamping itu dengan menggunakan media dalam proses pembelajaran dapat menarik perhatian peserta didik untuk lebih aktif dalam kegiatan pembelajaran. Hal ini sejalan dengan manfaat media yang diungkapkan Sudjana \& Rivai (2010: 2) terkait dengan manfaat media pembelajaran dalam proses belajar peserta didik antara lain: (1) pengajaran lebih menarik perhatian peserta didik sehingga menumbuhkan motivasi belajar, (2) bahan pembelajaran lebih bermakna sehingga mudah dipahami siswa dan tujuan pembelajaran mudah tercapai dengan baik, (3) metode pengajaran lebih bervariasi sehingga siswa tidak bosan dan guru tidak kehabisan tenaga, dan (4) peserta didik lebih banyak melakukan kegiatan belajar.

Beberapa penelitian juga membuktikan terhadap penggunaan media dalam proses pembelajaran yang menunjukkan bahwa proses dan hasil belajar para peserta didik menunjukkan perbedaan antara pembelajaran menggunakan media dengan tanpa media. Penggunaan media juga erat kaitannya dengan proses berpikir manusia, yaitu dimulai dari berpikir sederhana menuju berpikir kompleks (Sudjana \& Rivai, 2010: 3). Dengan demikian, penggunaan media sangat dianjurkan dalam pembelajaran untuk meningkatkan kualitas serta menjadikan pembelajaran lebih bermakna.

\section{KESIMPULAN \& SARAN}

Kesimpulan yang diperoleh berdasarkan hasil penelitian adalah sebagai berikut: 1)Penggunaan media kartu gambar pada siswa kelas 3 MI DDI I Kota palopo memberikan suasana belajar yang lebih menyenangkan dan memicu siswa untuk berpikir kritis untuk menyelesaikan permasalahan yang berkaitan dengan gambar pada kartu 2) Terjadi perubahan hasil belajar siswa yang signifikan antara sebelum dan setelah menggunakan media kartu gambar, yakni sebelum menggunakan media yang dikembangkan diperoleh 6 siswa yang belum tuntas dan persentase ketuntasan kelas 79,31\%. Setelah menggunakan media diperoleh persentase ketuntasan secara klasikal 100\%.

Pengembangan media kartu gambar yang telah dilaksanakan oleh peneliti hanya terfokus pada kelas 3, khususnya semester 1 . Diharapkan dapat dikembangkan lebih jauh lagi oleh pemerhati pendidikan, baik oleh guru, mahasiswa, dosen maupun peneliti lainnya.

\section{DAFTAR PUSTAKA}

Arends. 1997. Model-model Pembelajaran Inovatif Berorientasi Konstruktivistis. Jakarta: Prestasi Pustaka Publisher.

Arsyad, A. (2013). Media pembelajaran. Jakarta: PT Raja Grafindo Persada.

Lie, A. 2004. Cooperative Learning. Jakarta: Grasindo.

Rusman, Dr. 2011. Model-model Pembelajaran Mengambangkan Profesionalisme Guru. Jakarta: PT Rajagrafindo Persada.

Trianto. 2007. Model-model Pembelajaran Inovatif Berorientasi Konstruktivistik. Jakarta: Prestasi Pustaka.

Widiyoko, E. P. 2009. Evaluasi Program Pembelajaran Panduan Praktis bagi Pendidik dan Calon Pendidik. Yogyakarta: Pustaka Belajar.

Soewandi, S. 2005. Perspektif pembelajaran di berbagai bidang. Yogyakarta: US

Sudjana \& Rivai. 2010. Media Pengajaran. Bandung: Sinar Baru Algensindo. 